\title{
Dynamics of Metallurgic Production in Emerging Countries
}

\author{
Yulia Viktorovna Razvadovskaya ${ }^{1} \&$ Inna Konstantinovna Shevchenko ${ }^{1}$ \\ ${ }^{1}$ Southern Federal University, Russian Federation \\ Correspondence: Yulia Viktorovna Razvadovskaya, Bolshaya Sadovaya Str., 105/42, Rostov-on-Don, 344006, \\ Russian Federation. E-mail: yuliyaraz@yandex.ru
}

Received: February 25, 2015 Accepted: May 3, 2015 Online Published: July 30, 2015

doi:10.5539/ass.v11n19p178

URL: http://dx.doi.org/10.5539/ass.v11n19p178

\begin{abstract}
The article presents the analysis of the development of production in metallurgic industry. Production rates and output are determined by two factors. The first factor of the metals consumption growth is the annual population growth, especially in emerging countries. The second factor is the process of industrialization in emerging countries. However, the dynamics of the production processes can affect the re-industrialization and the reshoring of industrial production. The article analyses the development of production in metallurgic industry in China and Russia.
\end{abstract}

Keywords: metallurgic industry, emerging countries, China, Russia, steel, cast iron

\section{Introduction}

Natural resources, including subsoil assets, are vital for human life on earth. However, at the same time the growing use of natural resources adversely affects the environment and ecological situation. The development and application of new resource-saving metal-processing technologies is the only way to reduce the negative impact of the metals consumption growth under conditions of the growing population. The pace of metal (steel, copper and aluminium) consumption growth has become especially high since the Second World War. According to Humphreys D. the metals consumption peak falls at a period between 2003 and 2008 and is associated with producer and consumer goods production growth in emerging countries, among them in China. The main conditions of metal consumption growth are world population growth and industrialisation in emerging countries.

A decline in natural resources output is an effective way to improve the ecological situation in the world (Graedel, 2003). But unfortunately the experience shows that recently natural resources output has only been growing, mainly because of the growth of population and metal consumer goods production. Experts predict the further growth of world population in the future (Figure 1).

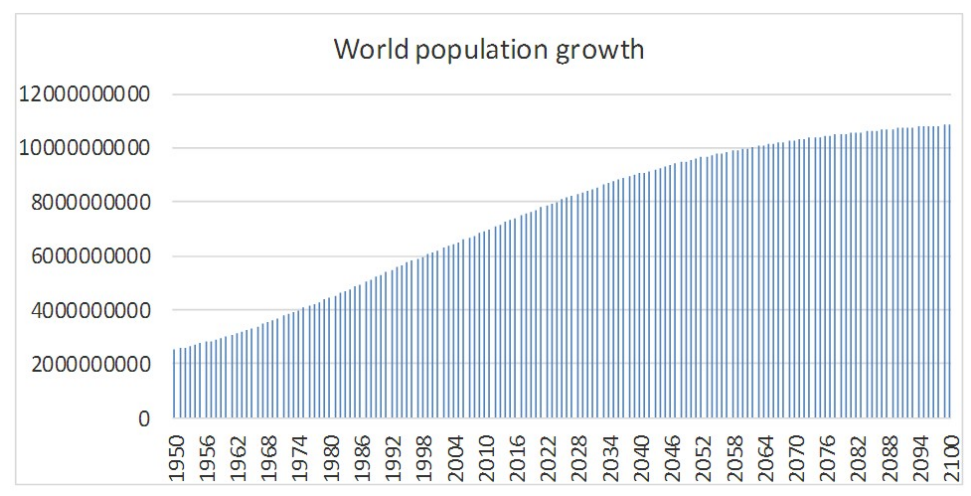

Figure 1. Growth of world population

Source: UN, Dept. of Economic and Social Affairs, Population Division (2011). World Population Prospects: The 2010 Revision.

Note: 1950-2010 are estimates and from 2011-2100 are projected populations in the medium-fertility variant. http://www.geohive.com/earth/his_history3.aspx 
The population grows most rapidly in emerging countries, among them in China. China leads in population and rate of its growth (Figure 2). That is why it accounts for the greatest share of the natural resources consumption, including metallurgic production. The projected trend of population growth not only in China, but in the whole world will lead to an increase in the use of resources in the future. This fact must motivate governments to find new and more effective methods of the natural resources use. There's a need to elaborate and implement new technologies which will enable to reduce the negative impact on environment and increase the efficiency of the raw material processing.

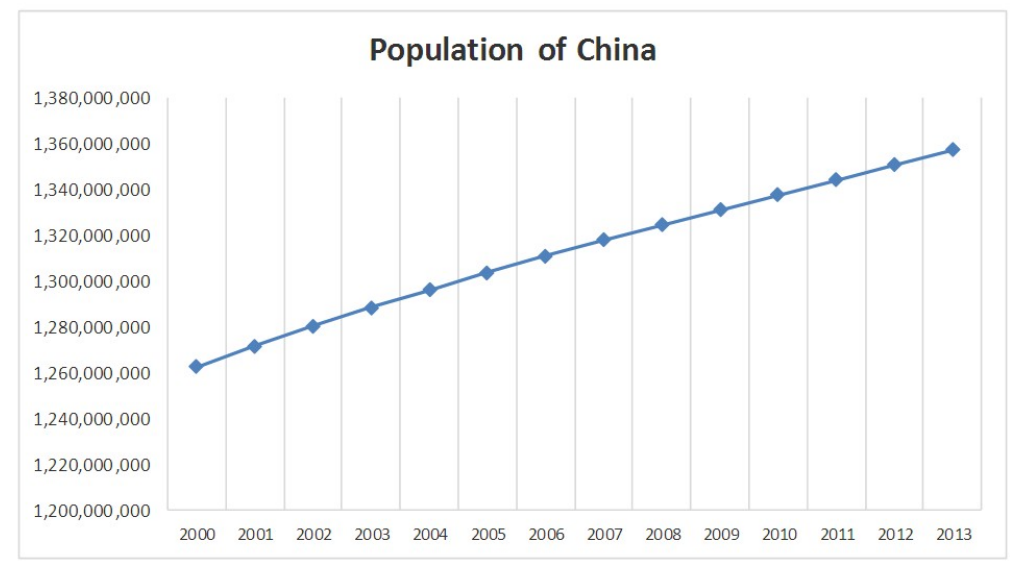

Figure 2. Population of China 2000-2013

Sources: The World Bank Group, All Rights Reserved. Legal. http://search.worldbank.org/quickview?name=\%3Cem $\% 3$ EPopulation $\% 3 \mathrm{C} \% 2 \mathrm{Fem} \% 3 \mathrm{E} \% 2 \mathrm{C}+$ total\&id=SP.POP. TOTL\&type $=$ Indicators\&cube_no $=2 \& q$ term $=$ population

Another condition of the metallurgic production growth is the process of industrialisation in emerging countries. The growing share of the natural resources consumption accounts for the emerging countries. It is caused by the rapid development of such emerging countries as China and India. In the early 2000s the share of emerging countries in the global economic growth exceeded the share of developed countries. China was the main, though not only component of this growth. Russia, India, South-East Asian countries, Latin America and Africa also account for the significant part of this growth. One of the main features of countries in the process of industrialisation is the fact that their development is connected with the consumption of large amounts of materials including metals. It occurs because the process of industrialisation on its early stages requires great expenses for the infrastructure development (Williamson, 1985).

The construction and modernization of manufacturing companies, power plants, ports, railroads, and the construction of shops, offices and houses require a large amount of producer goods. Another feature of countries in the process of industrialisation is the growth of personal incomes. This results in growth of consumption of durable goods, such as cars, TV sets, refrigerators. Durable goods consumption growth requires the increase of metal mining and processing.

\section{Methods}

Such factors as industrialization in emerging countries and population growth directly result in the metal consumption growth. These factors determine the glut of metallurgic production, which started from the beginning of World War II and reached a peak in the period between 2003 and 2008. The metal consumption growth during World War II was caused by the need to expand military might, militarization of economy, mass weapons production, railway construction (Radetzki, 2006). After the end of the war in many countries buildings, roads and plants were destroyed and needed reconstruction, which also resulted in higher demand for metallurgic production.

Over the hundred years, the metallurgic life cycle has seen several ups and downs, which was reflected in metal price rises and falls and thus affected the metallurgic production output, including steel production (picture 3). In the beginning of the XXI century the active development of information technologies caused an outflow of investments from metallurgy. Intellectual resources, communications, services, intangible goods became the 
basis of the new economy (Coyle, 1999). This was the reason for a cut in metal prices during the period between 1998 and 2002, but the volume of raw materials kept increasing even at that period.

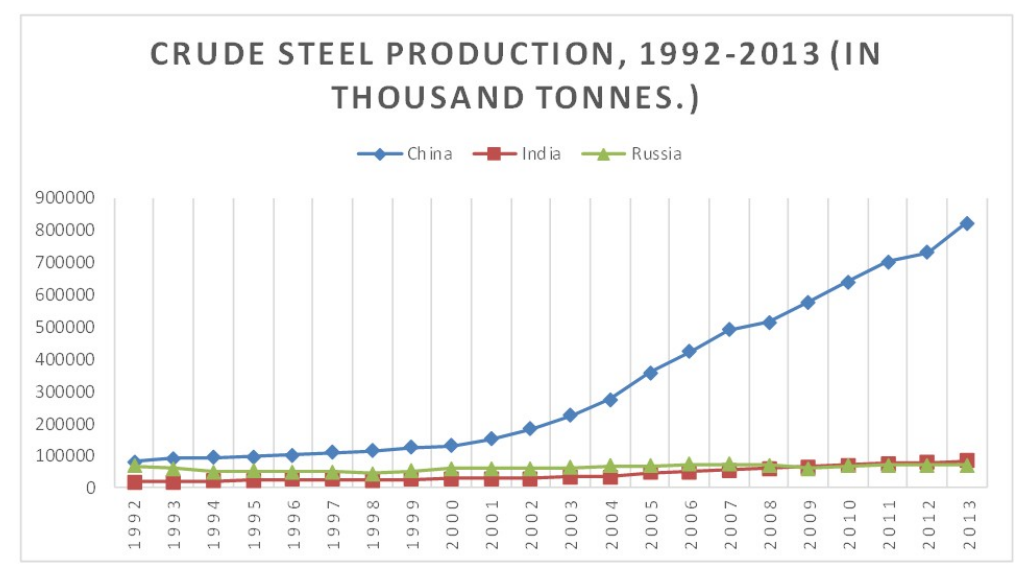

Figure 3. Crude steel production, 1992-2013 In thousand tonnes

Source: The World Steel Association http://www.worldsteel.org/dms/internetDocumentList/statistics-archive/ production-archive/steel-archive/steel-annually/steel-annually-1980-2013/document/steel\%20annually\%2019802013.pdf

The financial crisis in developed countries affected the metallurgic production price up to 2002. At the same time China intensively increased the volume of metals (including steel) produced and became more than three times more productive than Russia and India.

In 2003 there was a structural rise at the consumer goods market (Garren, 2003) and the demand for consumer goods started to outrun the commercial production which certainly caused a rise in prices of industrial goods, including metallurgic production. By the end of 2003 the background for the long-term growth of metallurgy had been formed and the output of metallurgic production in Russia and India began to increase. China still leads in a steel production level among world's leading metallurgic producers (Figure 3). Zink production in China also plays an important role in industrial development. Its production is associated with high domestic needs, so the raw materials production increases annually (Figure 4).

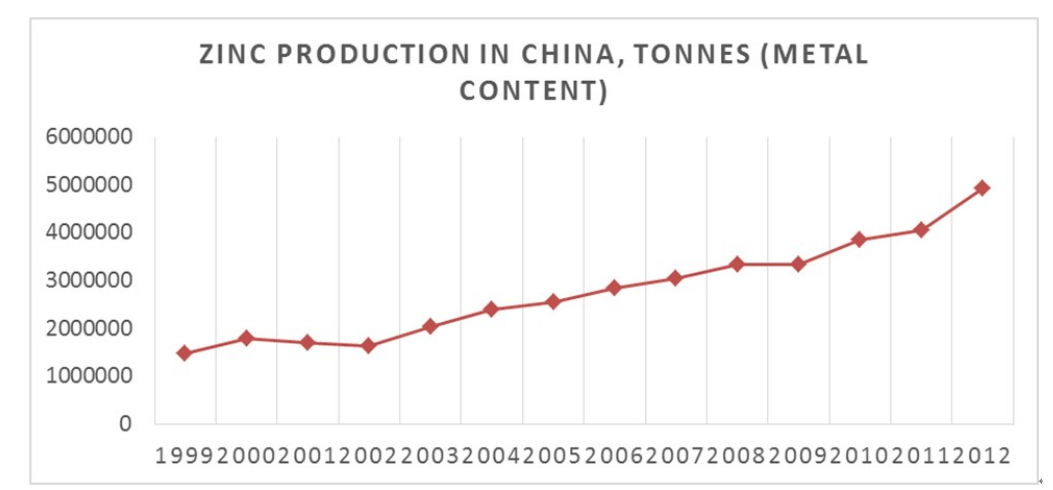

Figure 4. Dynamic of production zinc 1999-2012 in China

Source: Minerals UK is the British Geological Survey (BGS) Centre for Sustainable Mineral Development, The World Mineral Statistics dataset: 100 years and counting; Mineral Information and Statistics for the BRIC countries. https://www.bgs.ac.uk/mineralsuk/statistics/worldStatistics.html

Despite the signs of a crisis in a global environment metal prices continued to grow and in 2005 experts defined the peak in prices rise in metallurgy (Heap, 2005).

In 2006 the growth of global economy was maintained at a level of 5\% which kept the basis for the high demand for all raw material resources. Manufacturing companies increased natural resources production attempting to 
meet all demand for raw materials, but the production level could not do it. Despite of mortgage bubble problems in American economy, raw material prices fell insignificantly and there still was the trend of high metallurgic production prices. Only in the first half of 2008 the prices started to fall gradually. This affected the steel production output in Russia and India, which is shown in picture 3. The global economic crisis of 2008 struck all developed countries' economies, but the emerging countries haven't suffered from it so much. This was due to the high resource intensiveness of the emerging countries and high domestic demand for resources, including metallurgic production.

At the same time since 2007 the China metallurgic production share in global exports has started to grow. This is caused by the fact that China economy has become investment-attractive because of the low-cost labour and raw materials availability under conditions of the global economy crisis. The external investments in Chinese metallurgy enabled the high paces of its growth. The Chinese economy began to develop faster than economies of developed countries (Humphreys, 2010).

Positive dynamics in metallurgy development can also be observed in India, through its paces are not as high as in China (Figure 3). As already mentioned, emerging countries usually have a high domestic consumption of resources, which increases the demand for raw materials and high metallurgy production paces. In Indian economy the consumption is lower than in China, which is due to lower personal incomes and even a lower consumption level. The second factor of the economy development at early stages of industrialisation is low-cost labour, which attracts new investments in the economy.

Production figures of metallurgy in Russia are higher than those in India (Figure 3). Russia is the world's leader in iron-ore raw material stocks. (Russian Manufacturer). The large number of metal ore deposits allows exporting large volumes of metallurgy production. Russia exports mainly ferrous metals, the share of highly refined metals is relatively low, lower than in China. Nowadays Russia produces above $100 \mathrm{mln}$. tons of salable metal ore and holds the fifth place according to this indicator.

The structural change in global production forms different conditions for the developing economies which undergo the process of industrialization. Rates of Russia in the global metallurgic production are relatively low, which makes it necessary to find out the reasons for such a lag.

\section{Results}

As mentioned above, the share of emerging countries in global economic growth has been increasing in the last decade. There is an investment outflow in emerging countries, which have become new and powerful corporative players in global economy. Many studies are devoted to this topic (Lall, 1983, Kumar, 1998, pp. 177-194; 2008, pp. 242-261; Aykut \& Ratha, 2004, pp. 149-177; UNCTAD, 2006, 2013). The emerging countries are at the stage of establishing the new type of economy, form the network of international corporations based on available raw materials and technologies. The main strategy of the emerging countries is to increase their rate in the global environment through the export growth.

During the last decade the China economy has been growing at a very fast pace, exceeding the global economic growth. The peak of the growth in China falls on the information technologies crisis period in 2003. At that period the entire world's investment resources were searching for the sphere for investing. China with its natural resources and low-cost labour suited for this role. That is why in the current decade the Chinese economy is becoming the center of active investing, just as the information technologies were in the 1990s. The surplus of the low-cost capital heats up the Chinese economy and creates conditions for the vigorous growth of different branches including metallurgy. The fast paces of the Chinese economy growth marked the beginning of the shift of the consumption structure towards consumption goods (Wolf, 2003).

By 2004 China GDP growth reached 10\% with the parallel growth of exports. The instability of the global economy did not affect China. While the USA economy growth caused concern, in China measures were taken to prevent economic overheating. Though the global economy in 2004 was in recession, metal prices were higher than in 2003, and the China economy continued to increase its pace of growth. In 2005 the metal ore price rise reached $71 \%$. It was due to the high demand for metallurgic production (Pisano \& Shih, 2012). By comparison, the most significant metal price rise was observed in 1980 - by $19.5 \%$. The prices continue to rise in 2006, and China GDP growth was $10.4 \%$ in 2005 and $11.1 \%$ in 2006 . The global economy growth was only $5 \%$. The metallurgic production price rise was caused by the intensive producing and processing of natural resources to meet the growing needs of production and construction in emerging countries, especially in China.

In 2007 the global economy started to show signs of crisis, especially in the real estate market. But in Chinese economy the pace of economic growth continued to increase, its GDP increased by $11.4 \%$ in 2007 . Only in the 
second half of 2007 metallurgic production prices fell, but there was not any significant fall despite the growing USA and global economy crisis. The consumption of resources continues to grow and, according to Bergheim 94\% of China GDP was based on domestic demand, so even if the USA economy falls into crisis and stops purchasing Chinese goods, it will not weaken Chinese economy.

In the first half of 2008 came another metallurgic production price rise caused by the increased prices for copper and aluminum. In conditions of global profound crisis many countries accused China of artificial raising of metallurgic production price levels. In a relatively short period of time since 1990 prices for metallurgical production have dramatically increased. And it was only in the first half of 2008 when they started to fall.

The main reason for the metallurgic production price rise during the whole period since 1990 was the growing demand for raw materials and producer goods in China. More than a half of all investments in Chinese economy were in the industrial and real estate sectors. Investments in construction and infrastructure resulted in a directly proportional growth of investments in metallurgy. During the period between 2000 and 2008 the demand for aluminum in China increased by $20 \%$ annually, for steel - by $16 \%$ annually and for copper also by $16 \%$ annually. So during the given period the consumption of metallurgic production reached $2 / 3$ of the global consumption.

The main factors of China economy growth were large amounts of investment, which needed placement in the period of IT-crisis, and low-cost labor. This enabled to increase paces of the GDP growth through the export of the metallurgic production and other consumable goods.

To stimulate the growth of production of ferrous and non-ferrous metallurgy in the Order of the Ministry of Industry and Trade of the Russian Federation dated May 5, 2014 № 839 "On Approval of the Development Strategy of Russia's steel industry for 2014 - 2020 and up to 2030 and the Development Strategy of Russian ferrous metallurgy for 2014 - 2020 and up to 2030 "marked measures to support the industry. In the Strategy notes that the main determinants of increased demand for the products of the industry are: the development of the military-industrial complex, the construction of new fuel and energy complex, the development of infrastructure projects (2018 FIFA World Cup, the Universiade 2019), the development of railway projects transport, the implementation of the Development Strategy of the Russian Arctic. The Strategy notes that in the long term to 2030 demand for steel products will be formed by the fuel, energy, and machine-building complexes. It should be noted that the statement in the Strategy indicators are achievable, despite the economic crisis, as the main consumers of the industry are domestic enterprises. Lower oil prices may lead to the suspension of infrastructure projects in the energy sector in the short term. However, in the medium term increase in energy prices will lead to recovery and growth in demand for steel products from the fuel and energy complex. In contrast to the fuel and energy in the military-industrial complex is expected to increase consumption of metallurgical products, regardless of the fluctuations of economic conditions.

Increased demand for metallurgical products in the domestic market should lead to increased productivity. According to the Strategy productivity by 2030 is expected to grow by $30 \%$ in relation to 2012 . Provision of this indicator is planned due to: decommissioning inefficient capacities, production automation, increasing the share of value-added products, development of outsourcing. Due to these measures is planned to create new jobs: in 2015 - 2 thousand workplaces, in 2020 - 4 thousand workplaces, and in 2030 - 8 thousand workplaces people. It should be noted that in the context of the general economic instability and decline in demand for steel products from the fuel and energy and machine building, the creation of new jobs in the short and medium term could not be ensured.

Strategy development of the industry is forecast consistent growth investments, which in 2017-2020 will amount to 120 billion rub. 2021-2025. - 130 billion rub. And 2026-2030 - 140 billion rub. The main source of investment funds will own companies metallurgical complex, as well as attract resources from other sources, including bank loans, equipment leasing and sale of shares. In the face of declining demand for metallurgical products in the short and medium term, companies' own funds are likely to be mobilized to ensure the stability and preservation of existing market positions. In this regard, it can be assumed that the growth of investments in the years 2017-2020 to 120 billion rubs. is reached. Achievement of planned indicators of industry growth is possible only by increasing domestic demand for metallurgical products, which are more likely to be achieved no earlier than 2018-2020 years.

\section{Discussion}

This article has been proved that the population growth and industrialization in emerging countries cause the increase in the share of the consumed metallurgic production. Emerging countries consume more metallurgical products than developed ones. This is determined by the necessity of the infrastructure development. The consumption of raw materials, including metals is growing annually, which causes the negative environmental 
impact. The development of new resource-saving technology may become an effective means of tackling environmental problems. Growing with each passing year the consumption of raw materials, including metals aggravates the ecological situation in the world. Development of new resource-saving technologies can be an effective way to solve environmental problems.

China is the world-leader of metallurgic production. However, the greater share of the consumed production is domestic consumption. The key feature of the Chinese economy is it is very resource-consuming. So the global recessions do not negatively influence the prices of metals, and the GDP share in the world economy is increasing each year. China is a strong world player and occupies leading positions regarding the production of many goods.

Russia is also a leader in metal mining. However, compared to China, the volumes of the mining and processing are considerably lower. The main reason for this was the change of the political regime and the economy structure crisis in 1991 which weakened the metallurgic production. Shallow mines are predominating which lowers the share and quality of the raw materials produced. The share of non-ferrous metals mined in Russia does not even meet the domestic demand.

The following issues are to become the key trends of developing metallurgy in Russia:

- increasing the quality of the metallurgic production by developing new mines;

- applying new technologies which increase the effectiveness of processing metals;

- developing technologies lowering the negative impact on the environment.

\section{Conclusion}

Although Russia is an emerging country, its influence on the dynamics of the metallurgy development is not as strong as that of China. High rates of the metallurgy development in China are due to great shares from developed countries' investments. The Russian economy is not that investment-attractive for foreign investors. Without foreign investments, high rates of the metallurgy development cannot be achieved. Another problem of the Russian economy is the citizens' low incomes, which hinders the domestic consumption of metallurgic products. Despite the fact that Russia is at the stage of industrialization, the domestic consumption of metallurgic products is low and the demand is met by the Chinese metallurgic production.

The analysis of the impact of emerging countries on the metallurgy development shows that the greatest impact on the increase of metallurgic production is exercised by China, disposing of cheap labor force. Besides, China sees the high share of domestic consumption of production means and metallurgic products. Reshoring processes observed in 2011-2014, which mean moving production capacities from developing countries back to developed ones, can have significant impact on mining volumes and processing in china's metallurgy (Boston Consulting Group, 2013, 2014, Kinkel, 2009, pp. 154-165; 2012, pp. 696-720; Regalado, 2013, The Economist, 2013). However, reshoring processes will not have strong impact on Russian economy or its sectors including metallurgy (Shvetsov, 2012). This is due to the fact that, compared with other developing countries in Russia is small number of foreign origin companies and their return to developed countries will not have so significant impact on economic activity and production industries, including metallurgy.

\section{Acknowledgements}

Research is executed under the grant Russian Humanitarian Science Foundation (RHF) "Modeling of processes reindustrialization territorial branch complexes in the architecture of economic geographical space of Russia" № 15-02-00344 2015.

\section{References}

Aykut, D., \& Ratha, D. (2004). South-South FDI Flows: How Big are they? Transnational Corporations, 13(1), 149-177.

Boston Consulting Group. (2013). Majority of Large Manufacturers is Now Planning or Considering 'Reshoring' from China to the US. Retrieved December 4, 2013, from http://www.bcg.com/media/press releasedetails.aspx?id=tcm:12-144944

Boston Consulting Group. (2014). Global Workforce Crisis Puts \$10 Trillion at Risk in World Economy, Study Says. Retrieved from http://www.bcg.com/media/PressReleaseDetails.aspx?id=tcm:12-164660

Coyle, D. (1999). The weightless world: Strategies for managing the digital economy. MIT.

Garren, J. (2003). Signs of Structural Upturn, Global Commodities. UK Equity research. ABN AMRO. 
Graedel, T. E., \& Allenby, B. R. (2003). Industrial Ecology. NJ: Prentice Hall.

Heap, A. (2005). Riding the Super Cycle, Metals and Mining Global Equity Research. Citigroup.

Humphreys, D. (2010). The great metals boom: A retrospective. Resources Policy, 35(1-13). http://dx.doi.org/10. 1016/j.resourpol.2009.07.002

Kinkel, S. (2012). Trends in production relocation a back-shoring activities: Changing patterns in the course of the global economic crisis. Int. J. Oper. Prod. Manage, 32(6), 696-720. http://dx.doi.org/10.1108/01443 571211230934

Kinkel, S., \& Maloca, S. (2009). Drivers and antecedents of manufacturing off-shoring and back shoring-a German perspective. J. Purchasing Supply Manage, 15, 154-165. http://dx.doi.org/10.1016/j.pursup.2009. 05.007

Kumar, N. (1998). Emerging outward foreign direct investments from Asian developing countries, prospect and implications, in Globalization, Foreign Direct Investment and Technology Transfers, Impacts on and Prospects for Developing Countries (pp. 177-194). Routledge UNU/ INTECH: London. http://dx.doi.org/ $10.4324 / 9780203193624$

Kumar, N. (2008). Internationalization of Indian enterprises: Patterns, strategies, ownership advantages and implications. Asian Economic Policy Review, 3(2), 242-261. http://dx.doi.org/10.1111/j.1748-3131.2008. 00109.x

Lall, S. (1983). Multinationals from India, in the New Multinationals: The Spread of Third World Enterprises. New York: John Wiley \& Sons.

Pisano, G. P., \& Shih, W. C. (2012). Does America really need manufacturing? Harvard Bus. Rev., 90(3), 94-102.

Radetzki, M. (2006). The anatomy of three commodity booms. Resources Policy, 31(1). http://dx.doi.org/10. 1016/j.resourpol.2006.06.003

Regalado, A. (2013). Made in America, Again. MIT Technology Review January 11, 2013. Retrieved December 31, 2013, from http://www.technologyreview.com/news/509326/made-in-america-again/

Shvetsov, V. (2012). Mining Enterprise as an Indicator of the State of Economy. Russian Manufacturer, 12(143).

The Economist. (2013). Here, There and Anywhere. Special Report Outsourcing and Offshoring.

UNCTAD. (2006). World Investment Report 2006, FDI from Developing and Transition Economies: Implications for Development. United Nations: New York and Geneva.

UNCTAD. (2013). United Nations Conference on Trade and Development, 2013. Global Value Chains: Investment and Trade for Development. World Investment Report 2013. Geneva, Switzerland.

Williamson, O. E. (1985). The Economic Institutions of Capitalism. New York: Free Press.

Wolf, M. (2003). The World must learn to live with a wide-awake China. Financial Times, 12.

\section{Copyrights}

Copyright for this article is retained by the author(s), with first publication rights granted to the journal.

This is an open-access article distributed under the terms and conditions of the Creative Commons Attribution license (http://creativecommons.org/licenses/by/3.0/). 